MS33-P3 New polynuclear Re-M cyanide

$$
\text { complexes }(\mathrm{M}=\mathrm{Cu}, \mathrm{Ag})
$$

Monika K. Krawczyk ${ }^{1}$, Rahman Bikas ${ }^{1}$, Marta S. Krawczyk ${ }^{2}$

1. Faculty of Chemistry University of Wrocław, F. Joliot-Curie 14 St., 50-383 Wrocław, Poland

2. Department of Analytical Chemistry, Faculty of Pharmacy, Wrocław Medical University, Borowska 211A St.,50-556 Wrocław, Poland

email: monika.krawczyk@ifd.uni.wroc.pl

New class of mixed-metal square-shaped polynuclear clusters based on rhenium(I) phosphine complexes have been obtained. The heteronuclear complexes are comprising of the core that consists of $\mathrm{Re}$ and $\mathrm{Cu}$ or $\mathrm{Ag}$ atoms bridged by cyanide ligands resulting in the formation of cyclic structure with approximate square geometry. In studied complexes Re atoms are located in vertices of the square, while $\mathrm{Cu}$ or $\mathrm{Ag}$ atoms along with coordinated $\mathrm{CN}^{-}$ligands form their sides.

*Permanent adress: Institute of Experimental Physics, University of Wrocław, M. Borna 9, 50-204 Wrocław, Poland Finacial support: National Science Center (Grant NCN UMO-2013/11/N/ST5/01375)

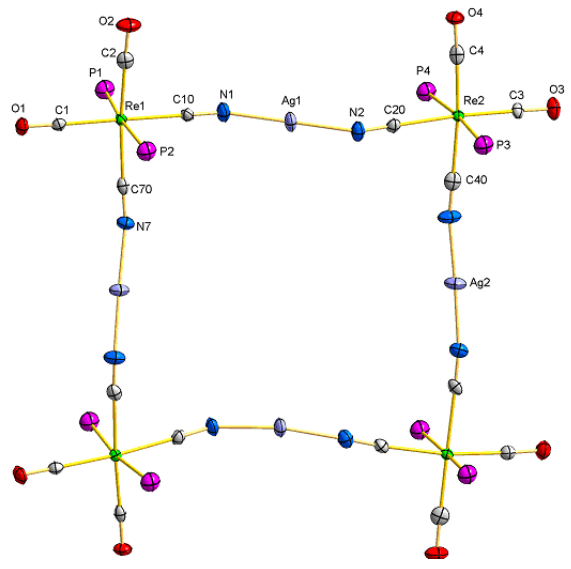

Figure 1. Structure of square-shaped $\{\operatorname{Re}(\mu-\mathrm{CN}) \operatorname{Ag}(\mu-\mathrm{NC})(\mathrm{CO}) \mathrm{P}\}$ unit in studied complex. The aromatic rings attached to phosphorus atoms in $\mathrm{PPh}_{3}$ groups are omitted for clarity.

Keywords: rhenium complexes, cyanide complexes, heteronuclear clusters

\section{MS33-P4 Disappearing Superstructure in Crystals of Pentaphosphaferrocene-Based Supramolecules}

Eugenia V. Peresypkina
Scheer $^{1,2}$
Alexander V. Virovets

1. Institute of Inorganic Chemistry, University of Regensburg, Germany

2. Nikolaev Institute of Inorganic Chemistry SB RAS, Novosibirsk, Russia

email: peresyp@niic.nsc.ru

Since 2002, we have being systematically investigating an inorganic analogue of ferrocene, pentaphosphaferrocene, $\left[\mathrm{Cp}^{\mathrm{R}} \mathrm{Fe}\left(\eta^{5}-\mathrm{P}_{5}\right)\right]\left(\mathrm{Cp}^{\mathrm{R}}=\eta^{5}-\mathrm{C}_{5} \mathrm{R}_{5}\right.$, $\left.\mathrm{R}=\mathrm{Me}\left(\mathrm{Cp}^{*}\right), \mathrm{CH}_{2} \mathrm{Ph}\left(\mathrm{Cp}^{\mathrm{Bn}}\right), \mathrm{PhC}_{4} \mathrm{H}_{9}\left(\mathrm{Cp}^{\mathrm{BIG}}\right)\right)$. It showed an unprecedented ability to assemble in giant supramolecules [1-7] when reacted to $\mathrm{Cu}(\mathrm{I})$ halides $(\mathrm{X}=$ $\mathrm{Cl}, \mathrm{Br}, \mathrm{I})$. These supramolecules reach $2.1-4.6 \mathrm{~nm}$ in size and can be isolated in astonishingly high yields. Their molecular structure is usually based on inorganic hollow cage, in which the cyclo- $\mathrm{P}_{5}$ ring of the $\left[\mathrm{Cp}^{\mathrm{R}} \mathrm{Fe}\left(\eta^{5}-\mathrm{P}_{5}\right)\right]$ ligand is coordinated to single or various aggregated $\mathrm{CuX}$ units. The single-layered cages often follow fullerene topology involving single $\mathrm{CuX}$ units [1-4]. The multi-layered cages $[1-2,6]$ are constructed of $\mathrm{Cu}_{n} \mathrm{X}_{m}$ polynuclear fragments.

The X-ray structural analysis of these compounds faces many difficulties as low diffraction power, disorder in $\mathrm{Cu} \mathrm{X}_{\mathrm{p}}$ halide core, disorder of guest molecules and $\mathrm{Cp}^{\mathrm{R}}$ ligands. The disorder can be interpreted as formation of solid solutions of co-crystallizing supramolecules with different, but similar structure. In some cases, we observed superstructural effects pointing to partial ordering. The aging of the crystals in the mother liquor unexpectedly leads the superstructure to disappear. For example, the diffraction pattern of freshly prepared $\left(\mathrm{CH}_{2} \mathrm{Cl}_{2}\right)_{34} @\left[\left(\mathrm{Cp}^{\mathrm{Bn}} \mathrm{FeP}_{5}\right)_{12}(\mathrm{CuI})_{54}(\mathrm{MeCN})_{146}\right]$

demonstrates superstructural ordering accompanied with doubling of the triclinic unit cell (see figure 1, blue). In the supercell two crystallographically unique supramolecules are related by pseudo body-centering translation. While aging, the diffraction pattern shows as superstructural reflections gradually fade. The resulting subcell (figure 1, red) contains only one unique supramolecule [1]. Other examples will also be discussed.

This work was supported by ERC grant AdG339072-SELFPHOS.

[1] F. Dielmann, C. Heindl, F. Hastreiter, E.V. Peresypkina et al (2015) Chem.-A Eur. J., 21, 6208.

[2] S. Heinl E. V. Peresypkina, J. Sutter, M. Scheer (2015) Angew. Chem. Int. Ed., 54, 13431.

[3] J. Bai, A. V. Virovets, M. Scheer (2003), Science, 300, 781 .

[4] M. Scheer, J. Bai, B. P. Johnson et al (2010), Chem. Eur. J. 18, 2092.

[5] C. Heindl, E. V. Peresypkina, A.V. Virovets et al (2015) J. Am. Chem. Soc., 137, 10938.

[6] C. Schwarzmaier A. Schindler, C. Heindl et al (2013) Angew. Chem. Int. Ed., 52, 10896.

[7] E. Peresypkina, C. Heindl, A. Schindler et al (2014) Z. Kristallogr., 229, 735. 